\title{
STRUKTUR KOMUNITAS MAKROZOOBENTOS PADA SALURAN MATA AIR LANGLANG DENGAN VEGETASI RIPARIAN YANG BERBEDA DI DESA NGENEP, KABUPATEN MALANG, JAWA TIMUR
}

\author{
Devi Armita ${ }^{1 *}$, Hafizhah Al Amanah², Syarif Hidayat Amrullah ${ }^{1}$ \\ ${ }^{1}$ Jurusan Biologi \\ Fakultas Sains dan Teknologi UIN Alauddin Makassar \\ Jl. Sultan Alauddin No. 63, Kabupaten Gowa, Sulawesi Selatan. 92113 \\ *E-mail: devi.armita@uin-alauddin.ac.id \\ ${ }^{2}$ Program Studi S-3 Ilmu Pertanian \\ Sekolah Pascasarjana Universitas Hasanuddin \\ Jl. Perintis Kemerdekaan KM.10, Kota Makassar, Sulawesi Selatan. 90245
}

\begin{abstract}
Abstrak: Penelitian ini bertujuan untuk mengetahui struktur komunitas makrozoobentos pada saluran mata air Langlang yang terdapat di Desa Ngenep Kabupaten Malang sebagai interpretasi dari kualitas perairan dengan melihat pengaruh dari kualitas riparian yang ada di sekitar mata air tersebut. Lokasi penelitian terdapat di Desa Ngenep, Kecamatan Karangploso, Kabupaten Malang, Jawa Timur. Pengambilan dan analisis contoh air dilakukan di lokasi pengambilan sampel (in situ) dan di laboratorium. Parameter kualitas air yang dianalisis dan dikaji adalah parameter $\mathrm{pH}$, kecerahan, DO, konduktivitas, kecepatan arus, kedalaman, turbiditas, substrat, dan suhu. Lokasi penelitian dilakukan di dua stasiun dengan tiga segmen pada tiap stasiun. Penentuan lokasi sampling (stasiun) dilakukan dengan metode purposive sampling yang didasarkan pada kondisi riparian yang terdapat di saluran irigasi sehingga dapat dibandingkan pengaruh kondisi riparian terhadap kualitas perairan di sekitarnya. Metode penelitian yang digunakan adalah menggunakan pendekatan deskriptif yaitu memberi gambaran tentang kualitas air di saluran mata air Langlang. Hasil yang diperoleh terkait struktur komunitas makrozoobentos yang ditemukan pada stasiun I dan stasiun II relatif sama. Pada stasiun I ditemukan 14 taksa dengan indeks diversitas (H') sebesar 3,35 sedangkan pada stasiun II ditemukan 15 taksa dengan indeks diversitas (H') sebesar 2,86. Sedangkan untuk penentuan kualitas air berdasarkan nilai Family Biotic Index (FBI) diperoleh hasil yang menunjukkan bahwa nilai FBI stasiun I sebesar 4,19 yang berarti kualitas air pada stasiun ini berada pada kategori sangat bagus, sedangkan stasiun II sebesar 4,56 yang berarti kualitas air pada stasiun ini berada pada kategori bagus. Berdasarkan hasil analisis vegetasi yang dilakukan pada tiap stasiun, diperoleh hasil yang menunjukkan bahwa vegetasi riparian pada stasiun I lebih bagus bila dibandingkan vegetasi riparian pada stasiun II, dilihat dari persentase penutupan jenis tumbuhan baik itu pohon, semak, maupun herba. Hasil korelasi Pearson antara kelimpahan makrozoobentos dan persentase tutupan riparian menunjukkan bahwa persentase penutupan jenis tumbuhan pada vegetasi riparian akan mempengaruhi kelimpahan makrozoobentos yang terdapat di perairan tersebut.
\end{abstract}

Kata Kunci: FBI, indeks diversitas, kualitas air, makrozoobentos, riparian 


\section{PENDAHULUAN}

$\mathrm{V}$

egetasi riparian merupakan bentang alam yang memegang peranan yang sangat penting dalam ekosistem karena berfungsi sebagai barrier masuknya nutrien berlebih dari tanah ke badan air yang bisa mempengaruhi kualitas suatu perairan. Selain sebagai barrier, vegetasi riparian juga bisa berfungsi sebagai sumber bahan-bahan organik dan energi bagi biota-biota yang terdapat di perairan (Kemalasari et al., 2011). Namun dengan semakin meningkatnya jumlah penduduk, semakin meningkat pula luas daerah alami yang beralih fungsi menjadi lahan pertanian, perkebunan, dan bahkan pemukiman sehingga terjadi pula penurunan vegetasi riparian yang menyebabkan kualitas perairan di sekitarnya juga mengalami penurunan.

Perubahan kondisi perairan yang terjadi dapat digambarkan melalui keberadaan biota di perairan. Biota yang hidup dalam suatu ekosistem melakukan adaptasi terhadap perubahan lingkungan yang terjadi. Apabila perubahan lingkungan tidak lagi mampu diadaptasi oleh biota, maka akan terjadi perubahan komposisi atau suksesi dari komunitas biota yang hidup dalam ekosistem tersebut. Berdasarkan hal tersebut, keberadaan suatu komunitas biota dapat digunakan sebagai petunjuk untuk menduga kondisi atau kualitas lingkungan suatu ekosistem atau dengan kata lain, suatu kelompok atau komunitas biota dapat berperan sebagai bioindikator kualitas lingkungan suatu ekosistem (Pratiwi et al., 2017).

Salah satu jenis biota yang sering digunakan sebagai bioindikator suatu perairan adalah makrozoobentos. Makrozoobentos merupakan organisme dasar perairan yang hidup di permukaan atas ataupun berada di dalam sedimen dasar perairan yang hidupnya merayap ataupun menggali lubang dan berperan penting di dalam rantai makanan (Ulfah et al., 2012). Biota ini juga berperan penting dalam proses dekomposisi dan mineralisasi material organik yang masuk ke dalam perairan (Sidik et al., 2016). Penggunaan organisme ini sebagai bioindikator karena sifatnya yang hidup menetap (sesile) pada suatu perairan dan memiliki daya adaptasi yang beragam (bervariasi) terhadap kondisi lingkungan. Penggunaan analisis biologi dalam menentukan suatu kondisi perairan dibandingkan analisis kimia dan fisika air dikarenakan sifat perairan yang dinamis sehingga memungkinkan terjadinya penyimpangan-penyimpangan hasil pengukuran karena dipengaruhi kondisi sesaat (Ridwan et al., 2016). Oleh karena itu dalam penentuan kondisi perairan perlu menyandingkan analisis fisika, kimia dan biologi untuk mendapatkan hasil yang lebih akurat.

Berdasarkan hal tersebut, perlu dilakukan penelitian terkait dengan struktur komunitas makrozoobentos yang dikaitkan dengan kondisi vegetasi riparian untuk melihat peranan dari riparian sebagai komponen ekosistem yang berperan menjaga kualitas air dari berbagai macam pencemaran akibat aktivitas manusia.

\section{METODE PENELITIAN}

Penelitian dilakukan di saluran mata air yang terdapat di dekat Sumber air Langlang, Desa Ngenep, Kabupaten Malang, Jawa Timur. Data makrozoobentos yang diperoleh dianalisis di Laboratorium Ekologi dan Diversitas Hewan Jurusan Biologi, Fakultas Matematika dan Ilmu Pengetahuan Alam, Universitas Brawijaya. Data diambil di saluran irigasi pada dua stasiun yang berbeda dengan titik koordinat $07^{\circ} 53^{\prime} 41.2^{\prime}$ ' LS

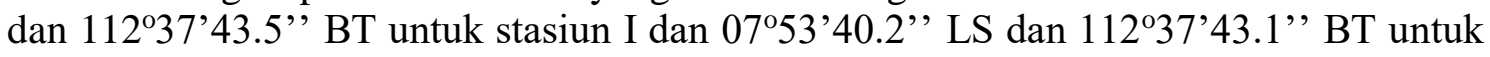
stasiun II dengan ketinggian berkisar antara 532-552 meter di atas permukaan laut (mdpl). 

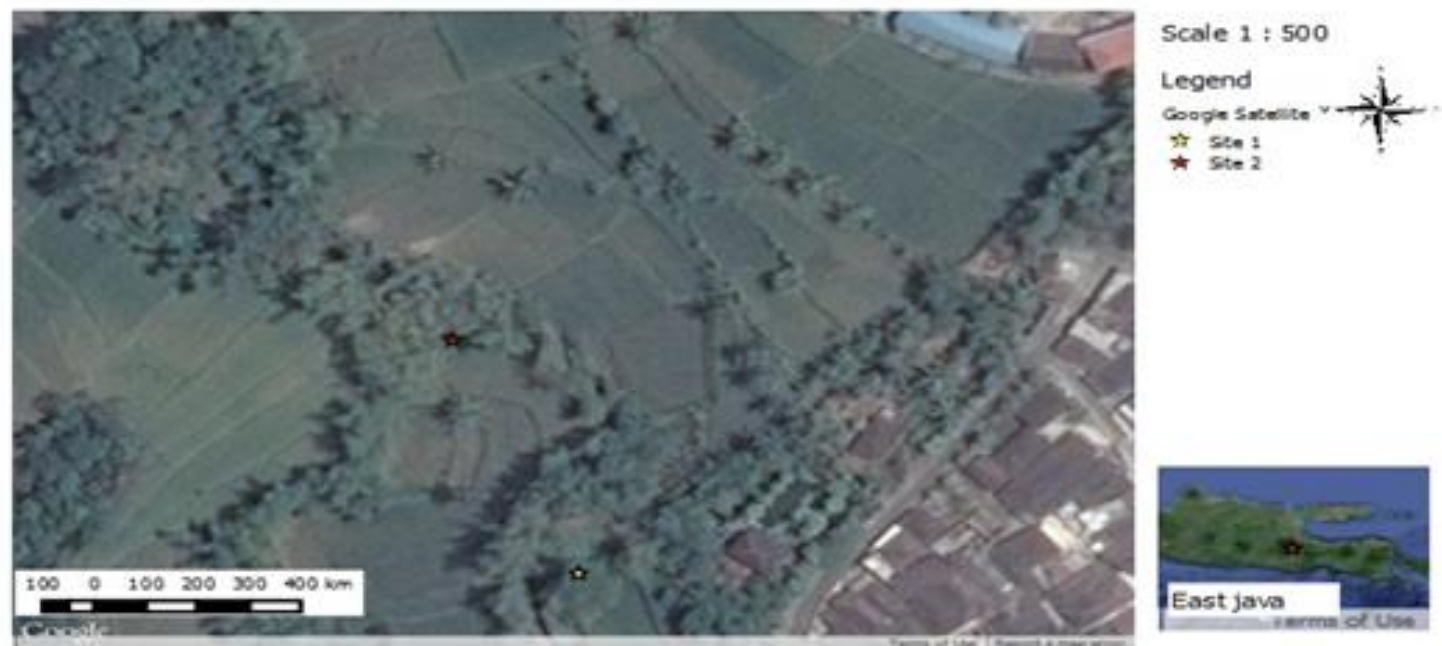

Gambar 1. Peta lokasi pengambilan sampel di saluran mata air Langlang, Desa Ngenep

Penentuan lokasi sampling (stasiun) dilakukan dengan metode purposive sampling yang didasarkan pada kondisi riparian yang terdapat di saluran irigasi. Penilaian struktur vegetasi meliputi pengukuran komposisi tumbuhan (herba, semak, dan pohon) serta persentase penutupannya. Setelah itu dilakukan dokumentasi vegetasi riparian dan tutupan kanopi vegetasi di atas badan sungai untuk membedakan kondisi dari masingmasing stasiun.

Pengambilan sampel makrozoobentos dilakukan dengan menggunakan jaring surber (dip net) yang berukuran $25 \times 40 \mathrm{~cm}$ dan dilakukan sebanyak 3 kali pada tiap stasiun. Sebelum dilakukan pengambilan sampel, pada tiap stasiun dilakukan pengukuran faktor fisika-kimia yang meliputi $\mathrm{pH}$, DO, suhu, konduktivitas, kecepatan arus, kecerahan, kedalaman, dan turbiditas. Pengambilan sampel makrozoobentos dilakukan dengan meletakkan jaring surber di dasar perairan dengan posisi jaring diletakkan menghadap arah datangnya arus. Makrozoobentos diambil dengan cara mengeruk bagian luasan petak, setelah selesai hasil sampling disortir dan hasil sortiran dimasukkan ke dalam botol sampel dan diawetkan dengan alkohol $70 \%$, selanjutnya dilakukan identifikasi di laboratorium (Rachman et al., 2016).

Untuk analisis data, dilakukan perhitungan indeks keanekaragaman ( $\left.\mathrm{H}^{\prime}\right)$, keseragaman (E), dan dominansi (D) makrozoobentos pada tiap stasiun kemudian dilakukan perhitungan nilai analisis korelasi pearson antara nilai $\mathrm{H}^{\prime}$ yang diperoleh dengan persentase penutupan vegetasi riparian pada tiap stasiun untuk melihat bentuk hubungan antara data yang dibandingkan. Dan untuk penentuan kualitas air, selain menggunakan nilai H' yang diperoleh juga dilakukan perhitungan Family Biotic Index (FBI) untuk mendapatkan interpretasi kualitas air yang lebih akurat.

\section{HASIL DAN PEMBAHASAN}

1. Kelimpahan Makrozoobentos

Makrozoobentos yang ditemukan di saluran Irigasi yang berada di sekitar Sakuran Mata Air Langlang terdiri dari 5 kelas, 11 ordo, dan 15 famili. Dari dua stasiun pengambilan sampel, jumlah makrozoobentos yang paling banyak ditemukan yaitu dari kelas Insecta yang terdiri dari Ordo Tricoptera, Plecoptera, Coleoptera, Ephemeroptera, Diptera, dan Odonata. Ordo Tricoptera merupakan ordo yang paling banyak ditemukan, baik itu pada stasiun I maupun stasiun II, namun jumlahnya pada stasiun II sangat 
mendominasi dibandingkan ordo yang lainnya (Gambar 2).

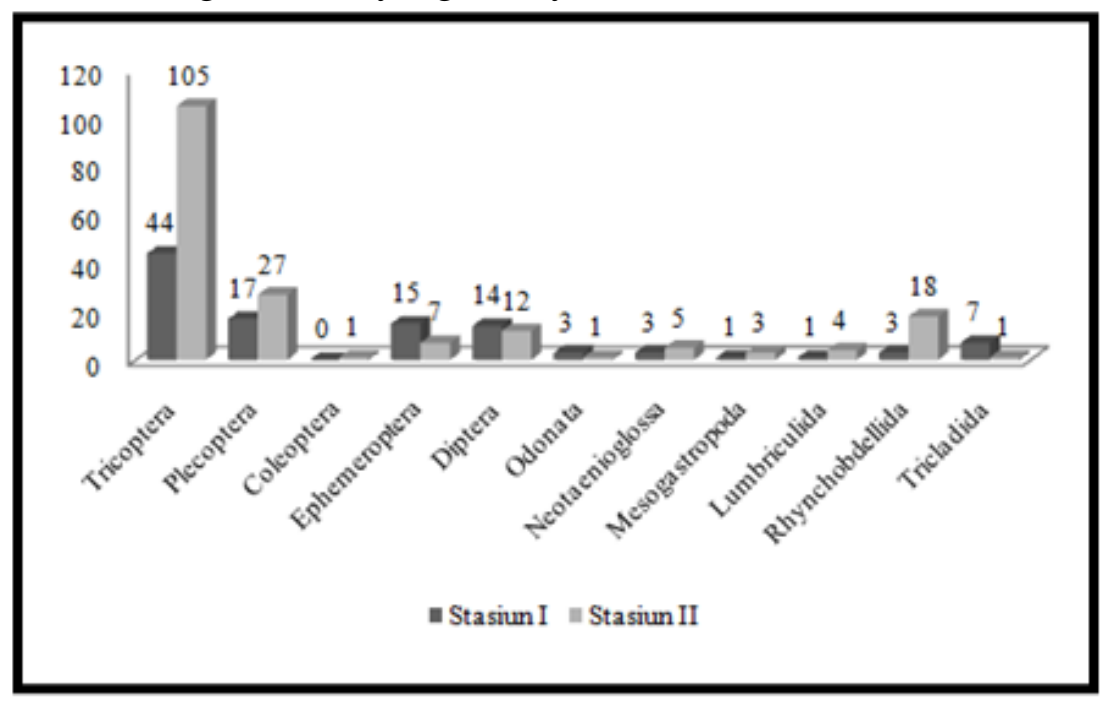

Gambar 2: Komposisi makrozoobentos pada tiap stasiun

Dari hasil perhitungan indeks keanekaragaman (H'), keseragaman (E), dan dominansi (D), diperoleh hasil yang menunjukkan bahwa H'dan E makrozoobentos pada stasiun I lebih tinggi dibandingkan pada stasiun II, namun untuk D makrozoobentos pada stasiun I lebih rendah dibandingkan stasiun II (Tabel 1). Brower et al (1998) menyatakan bahwa suatu komunitas dikatakan mempunyai keanekaragaman jenis yang tinggi apabila terdapat banyak spesies dengan jumlah individu masing-masing spesies relatif merata. Tolak ukur nilai indeks keanekaragaman juga dapat dilihat pada Tabel 2.

Sedangkan menurut Odum (1994), keanekaragaman jenis dipengaruhi oleh pembagian atau penyebaran individu dalam tiap jenisnya, karena suatu komunitas walaupun banyak jenisnya tetapi bila penyebaran individunya tidak merata maka keanekaragaman jenisnya dinilai rendah (Simamora, 2009). Sedangkan untuk indeks keseragaman menurut Krebs (1985), jika indeks keseragaman mendekati 0 berarti keseragamannya rendah karena ada jenis yang mendominasi dan bila mendekati 1 , maka keseragamannya tinggi dan menggambarkan tidak ada jenis yang mendominasi sehingga pembagian jumlah individu pada masing-masing jenis sangat seragam atau merata (Simamora, 2009). Berdasarkan hal tersebut dapat dikatakan bahwa indeks keseragaman makrozoobentos pada stasiun I lebih tinggi dibandingkan stasiun II karena pada stasiun II terdapat jenis makrozoobentos yang mendominasi dibandingkan jenis makrozoobentos lainnya.

Tabel 1. Indeks Keanekaragaman (H'), keseragaman (E), dan dominansi (D) makrozoobentos air pada tiap stasiun.

\begin{tabular}{lcc}
\hline \multicolumn{1}{c}{ Indeks } & \multicolumn{2}{c}{ Stasiun } \\
\cline { 2 - 3 } & I & II \\
\hline Keanekaragaman (H') & 2,319 & 1,982 \\
Keseragaman (E) & 0,726 & 0,483 \\
Dominansi (D) & 0,118 & 0,210 \\
\hline
\end{tabular}


Tabel 2. Tolak ukur nilai indeks keanekaragaman (H')

\begin{tabular}{cl}
\hline Nilai Tolak Ukur & \multicolumn{1}{c}{ Keterangan } \\
\hline $\mathrm{H}^{\prime}<1,0$ & $\begin{array}{l}\text { Keanekaragaman rendah, miskin, produktivitas sangat rendah sebagai } \\
\text { indikasi adanya tekanan yang berat dan ekosistem tidak stabil } \\
\text { Keanekaragaman sedang, produktivitas cukup, kondisi ekosistem } \\
\text { cukup seimbang, tekanan ekologis sedang } \\
\text { Keanekaragaman tinggi, stabilitas ekosistem baik, produktivitas } \\
\text { tinggi, tahan terhadap tekanan ekologis }\end{array}$ \\
\hline $\mathrm{H}^{\prime}>3,32$ &
\end{tabular}

Sumber: Wardoyo, 1989

Dari dua stasiun pengambilan sampel pada penelitian ini, jika dilihat dari indeks keanekaragaman makrozoobentos yang tinggi dapat dikatakan bahwa kualitas air pada saluran irigasi yang menjadi lokasi penelitian masih dalam kualitas yang bagus. Dari hasil pengukuran parameter fisika-kimia diperoleh data yang menunjukkan bahwa nilai $\mathrm{pH}$ pada stasiun I dan stasiun II masih dalam kisaran yang pada kisaran normal menurut PP. No. 82 Tentang Pengelolaan Kualitas Air dan Pengendalian Pencemaran Air. Namun untuk nilai DO (kandungan oksigen terlarut), baik itu untuk stasiun I maupun stasiun II jumlahnya relatif rendah (Tabel 3). Berdasarkan baku mutu air kelas I dan kelas II menurut PP. No. 82 Tahun 2001 untuk kelas I batas minimum DO yang diperbolehkan adalah $6 \mathrm{mg} / \mathrm{L}$ dan untuk kelas II adalah 4 mg/L. Namun menurut Sinambela (1999), kehidupan makrozoobentos perairan dapat bertahan jika ada oksigen terlarut minimum sebanyak $2 \mathrm{mg} / \mathrm{L}$ (Sinaga, 2009). Untuk nilai konduktivitas untuk stasiun I maupun stasiun II berada dalam kisaran normal karena berdasarkan FAO, nilai konduktivitas untuk saluran irigasi masih dikatakan normal jika berada pada kisaran 0,3 dS/m (Agustina $\&$ Endang, 2013). Sedangkan untuk suhu (temperatur) yang optimum untuk habitat makrozoobentos yaitu berkisar antara $20-30^{\circ} \mathrm{C}$ (Lusianingsih, 2011) dan untuk pH, sebagian besar biota perairan termasuk makrozoobentos sensitif terhadap perubahan $\mathrm{pH}$ dan memiliki kisaran pH optimum 7-8,5 (Effendi, 2003).

Tabel 3. Hasil pengukuran faktor fisika-kimia perairan pada tiap stasiun

\begin{tabular}{llccc}
\hline \multirow{2}{*}{ NO } & \multicolumn{1}{c}{ PARAMETER } & SATUAN & \multicolumn{2}{c}{ STASIUN } \\
\cline { 3 - 5 } 1. & pH Air & - & I & II \\
\cline { 3 - 4 } 2. & DO & $\mathrm{ppm}$ & 2.3 & 6.6 \\
3. & Temperatur & $0 \mathrm{C}$ & 2.5 & 3.0 \\
4. & Konduktivitas & $\mu \mathrm{s} / \mathrm{cm}$ & 108.9 & 22.4 \\
5. & Kecepatan Arus & $\mathrm{m} / \mathrm{s}$ & 0.8 & 112.9 \\
6. & Kecerahan & $\mathrm{cm}$ & 12 & 0.6 \\
7. & Substrat & - & Berbatu & 16 \\
8. & Kedalaman & $\mathrm{m}$ & 0.18 & Berbatu \\
9. & Turbiditas & $\mathrm{NTU}$ & 2.31 & 0.12 \\
\hline
\end{tabular}

2. Hubungan Antara Vegetasi Riparian dan Kondisi Perairan

Berdasarkan hasil analisis vegetasi yang dilakukan pada tiap stasiun, diperoleh hasil yang menunjukkan bahwa vegetasi riparian pada stasiun I lebih bagus bila dibandingkan vegetasi riparian pada stasiun II, dilihat dari persentase penutupan jenis tumbuhan baik itu pohon, semak, maupun herba (Gambar 3 dan Gambar 4). 


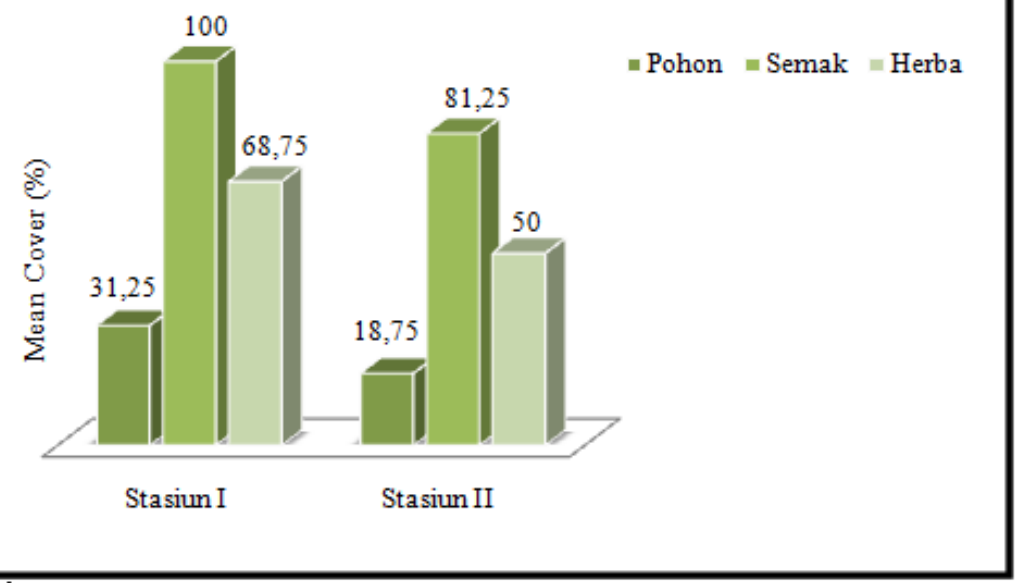

Gambar 3. Persentase penutupan vegetasi riparian pada tiap stasiun
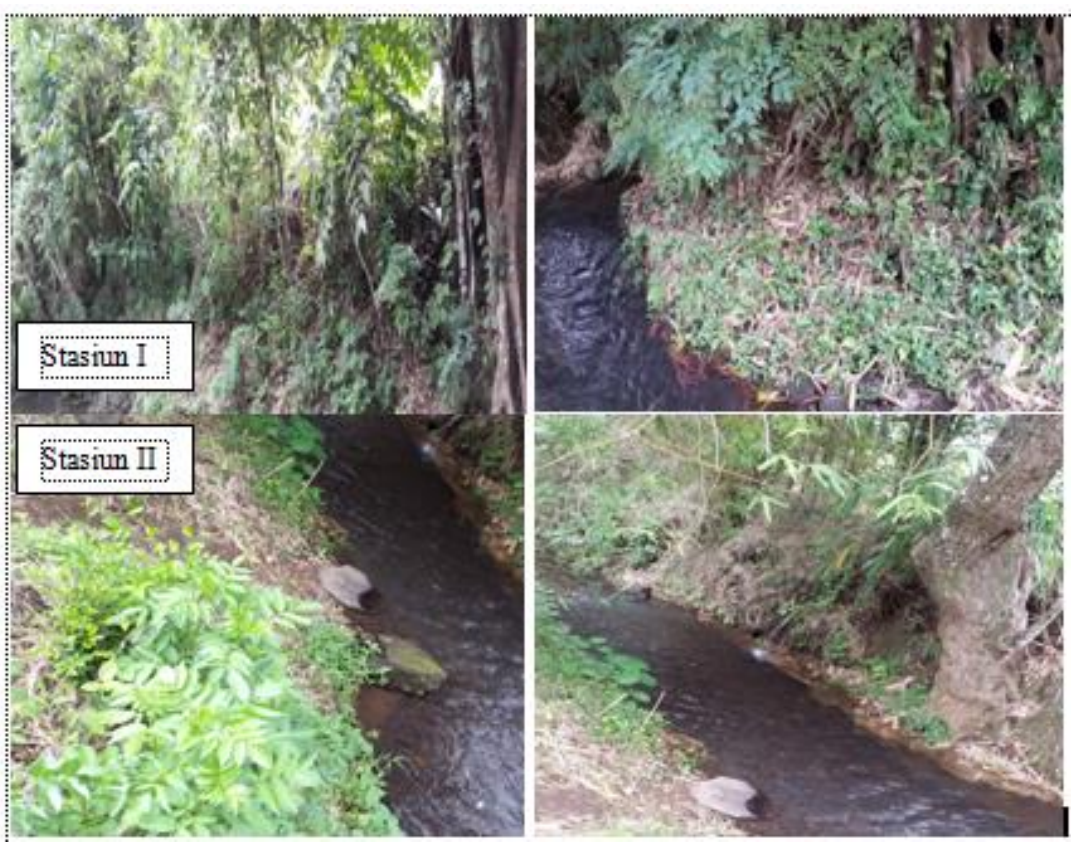

Gambar 4. Perbandingan vegetasi riparian pada stasiun I dan II

Dari hasil analisis korelasi pearson dengan membandingkan antara persentase penutupan jenis tanaman dengan indeks keanekaragaman $\left(\mathrm{H}^{\prime}\right)$ makrozoobentos pada tiap stasiun yang dilakukan untuk membuktikan bahwa kondisi vegetasi riparian mempengaruhi kelimpahan makrozoobentos diperoleh nilai korelasi sebesar +1 yang menunjukkan bahwa persentase penutupan jenis tumbuhan pada vegetasi riparian akan mempengaruhi kelimpahan makrozoobentos yang terdapat di perairan tersebut.

Berdasarkan hasil penentuan kualitas perairan berdasarkan Famili Biotik Indeks (FBI), diperoleh nilai FBI sebesar 4.19 untuk stasiun 1 (Tabel 4). 
Tabel 4. Hasil pengamatan makrozoobentos pada stasiun 1 berdasarkan Famili Biotik Indeks (FBI)

\begin{tabular}{cccccc}
\hline NO & NAMA FAMILI & ORDO & $\begin{array}{c}\text { JUMLAH } \\
(\mathbf{X i})\end{array}$ & $\begin{array}{c}\text { NILAI } \\
\text { TOLERANSI (ti) }\end{array}$ & Xi.ti \\
\hline 1 & Limnephilidae & Tricoptera & 5 & 4 & 20 \\
2 & Hydroptilidae & Tricoptera & 19 & 4 & 76 \\
3 & Hydropsychidae & Tricoptera & 20 & 4 & 80 \\
4 & Perlodidae & Plecoptera & 13 & 2 & 26 \\
5 & Leuctridae & Plecoptera & 4 & 0 & 0 \\
6 & Psephenidae & Coleoptera & 0 & 4 & 0 \\
7 & Caenidae & Ephemeroptera & 4 & 7 & 28 \\
8 & Baetidae & Ephemeroptera & 11 & 4 & 44 \\
9 & Simuliidae & Diptera & 14 & 6 & 84 \\
10 & Gomphidae & Odonata & 3 & 1 & 3 \\
11 & Hydrobiidae & Neotaenioglossa & 3 & 7 & 21 \\
12 & Bithyniidae & Mesogastropoda & 1 & 8 & 8 \\
13 & Lumbriculidae & Lumbriculida & 1 & 5 & 5 \\
14 & - & Rhynchobdellida & 3 & 10 & 30 \\
15 & Dugesiidae & Tricladida/ Planaria & 7 & 4 & 28 \\
& & & 108 & 70 & 453 \\
\hline
\end{tabular}

FBI $=4.19$

Berdasarkan perhitungan tersebut, diperoleh hasil yang menunjukkan bahwa kualitas air pada saluran irigasi di stasiun I masih dalam kondisi baik sekali atau sedikit terpolusi oleh bahan organik (Tabel 5).

Tabel 5. Interpretasi FBI untuk penentuan kualitas air

\begin{tabular}{lll}
\hline \multicolumn{1}{c}{ Famili Biotik Indeks } & \multicolumn{1}{c}{ Kualitas Air } & \multicolumn{1}{c}{ Tingkat Pencemaran } \\
\hline $0,00-3,75$ & Sangat baik & Tidak terpolusi bahan organik \\
$3,76-4,25$ & Baik sekali & Sedikit terpolusi bahan organik \\
$4,26-5,00$ & Baik & Terpolusi beberapa bahan organik \\
$5,01-5,75$ & Cukup & Terpolusi agak banyak \\
$5,76-6,50$ & Agak buruk & Terpolusi banyak \\
$6,51-7,25$ & Buruk & Terpolusi sangat banyak \\
$7,26-10,00$ & Buruk sekali & Terpolusi berat bahan organik \\
\hline
\end{tabular}

Sumber: Hilsenhoff, 1987 (Maruru, 2012)

Sedangkan untuk stasiun II diperoleh hasil perhitungan FBI sebesar 4.56 (Tabel 6), yang menunjukkan bahwa kualitas air pada saluran irigasi di stasiun II berada pada kategori baik atau terpolusi beberapa bahan organik berdasarkan kategori FBI (Tabel 5).

Tabel 6. Hasil pengamatan makrozoobentos pada stasiun 2 berdasarkan Famili Biotik Indeks (FBI).

\begin{tabular}{cccccc}
\hline NO & NAMA FAMILI & ORDO & JUMLAH (Xi) & NILAI TOLERANSI (ti) & Xi.ti \\
\hline 1 & Limnephilidae & Tricoptera & 3 & 4 & 12 \\
2 & Hydroptilidae & Tricoptera & 29 & 4 & 116 \\
3 & Hydropsychidae & Tricoptera & 73 & 4 & 292 \\
4 & Perlodidae & Plecoptera & 17 & 2 & 34
\end{tabular}




\begin{tabular}{cccccc}
5 & Leuctridae & Plecoptera & 10 & 0 & 0 \\
6 & Psephenidae & Coleoptera & 1 & 4 & 4 \\
7 & Caenidae & Ephemeroptera & 6 & 7 & 42 \\
8 & Baetidae & Ephemeroptera & 1 & 4 & 4 \\
9 & Simuliidae & Diptera & 12 & 6 & 72 \\
10 & Gomphidae & Odonata & 1 & 1 & 1 \\
11 & Hydrobiidae & Neotaenioglossa & 5 & 7 & 35 \\
12 & Bithyniidae & Mesogastropoda & 3 & 8 & 24 \\
13 & Lumbriculidae & Lumbriculida & 4 & 5 & 20 \\
14 & - & Rhynchobdellida & 18 & 10 & 180 \\
15 & Dugesiidae & Tricladida/ Planaria & 1 & 4 & 4 \\
\multicolumn{2}{c}{ Total } & & 184 & 70 & 840 \\
\hline
\end{tabular}

FBI $=4.56$

Berdasarkan data-data tersebut di atas, jika didasarkan dari indeks keanekaragaman (H') makrozoobentos pada tiap stasiun, untuk stasiun I berada dalam kategori perairan yang tidak tercemar karena memiliki nilai $\mathrm{H}^{\prime}>2,0$; dan untuk stasiun II berada dalam kategori tercemar ringan karena memiliki nilai H' yang berada pada kisaran antara 1,62,0 (Sinaga, 2009). Namun dari hasil penentuan kualitas air dengan menggunakan FBI diperoleh hasil yang berbeda meskipun tidak terlalu mencolok yaitu untuk stasiun I berada dalam kategori tercemar namun tingkat pencemarannya masih sangat rendah sedangkan untuk stasiun II berada dalam kategori tercemar ringan.

\section{KESIMPULAN}

Dari hasil penelitian yang dilakukan untuk membuktikan pengaruh vegetasi riparian terhadap kelimpahan makrozoobentos yang dapat digunakan sebagai bioindikator perairan menunjukkan bahwa vegetasi riparian akan berpengaruh terhadap kelimpahan makrozoobentos yang terdapat di perairan. Sebagaimana hasil pada penelitian ini yang menunjukkan bahwa stasiun dengan kondisi vegetasi riparian yang lebih bagus yaitu pada stasiun I memiliki indeks keanekaragaman (H') makrozoobentos yang lebih tinggi dibandingkan dengan stasiun II dan dari hasil analisis kualitas perairan dengan menggunakan FBI diperoleh hasil yang juga menunjukkan bahwa stasiun I memiliki kualitas air yang lebih bagus dibandingkan dengan stasiun II.

\section{DAFTAR PUSTAKA}

Agustina, L., \& Arisoesilaningsih, E. (2013). Variasi Profil Vegetasi Pohon Riparian di Sekitar Mata Air dan saluran Irigasi Tersier di Kabupaten Malang. Jurnal Biotropika, 1 (3), 85-89.

Brower, J. E., Zar, J. H., \& Ende, C.N. (1998). Field and Laboratory Methods for General Ecology. Boston, USA: Graw Hill

Edward, A. (2014). Kelimpahan Makrozoobenthos di Perairan Situ Pamulang. Al-Kauniyah Jurnal Biologi, 7(2), 69-73.

Kemalasari., Dellai., \& Choesin, D.N. (2011). Relationship Different Riparian Vegetation Cover with Stream Conditions in Cikapinis Stream, West Jawa. Jurnal Biologi Indonesia, 7 (2), 231-242.

Lusianingsih, N. (2011). Keanekaragaman Makrozoobenthos di Sungai Bah Bolon Kabupaten Simamulung Sumatera Utara. [Skripsi]. Medan: Universitas Sumatera Utara.

Maruru, S.M.M. (2012). Studi Kualitas Air Sungai Bone dengan Metode Biomonitoring. [Skripsi]. Gorontalo: Universitas Negeri Gorontalo.

Novianti, M., Widyorini, N., \& Suprapto, D. (2013). Analisis Kelimpahan Perifiton pada Kepadatan Lamun 
yang Berbeda di Perairan Pulau Panjang, Jepara. Journal of Management of Aquatic Resources. 2 (3), 219-225.

Pratiwi, N.T.M., Hariyadi, S., \& Kiswari, D.I. (2017). Struktur Komunitas Perifiton di Bagian Hulu Sungai Cisadane, Kawasan Taman Nasional Gunung Halimun Salak, Jawa Barat. Jurnal Biologi Indonesia, 13(2), 289-296.

Rachman, H., Priyono, A., \& Wardiatno, Y. (2016). Makrozoobenthos sebagai Bioindikator Kualitas Air Sungai di Sub DAS Ciliwung Hulu. Media Konservasi, 21(3), 261-269.

Ridwan, M., Fathoni, R., Fatihah, I., \& Pangestu, D.A. (2016). Struktur Komunitas Makrozoobentos di Empat Muara Sungai Cagar Alam Pulau Dua, Serang, Banten. Al-Kauniyah Jurnal Biologi, 9(1), 57-65.

Sidik, R.Y., Dewiyanti, I., \& Octavina, C. (2016). Struktur Komunitas Makrozoobentos di Beberapa Muara Sungai Kecamatan Susoh Kabupaten Aceh Barat Daya. Jurnal Ilmiah Mahasiswa Kelautan dan Peikanan Unsyiah, 1(2), 287-296.

Simamora, D.R. (2009). Studi Keanekaragaman Makrozoobentos di Aliran Sungai Padang Kota Tebing Tinggi. [Skripsi]. Medan: Universitas Sumatera Utara.

Sinaga, T. (2009). Keanekaragaman Makrozoobentos sebagai Indikator Kualitas Perairan Danau Toba Balige Kabupaten Toba Samosir. [Tesis]. Medan: Universitas Sumatera Utara.

Ulfah, Y., Widianingsih., \& Zainuri, M. (2012). Struktur Komunitas Makrozoobentos di Perairan Wilayah Morosari Desa Bedono Kecamatan Sayung Demak. Journal of Marine Research, 1(2), 188-196.

Wardoyo, S.T.H. (1989). Kriteria Kualitas Air untuk Pertanian dan Perikanan. Makalah pada Seminar Pengendalian Pencemaran Air. Bandung: Dirjen Pengairan Departemen Pekerjaan Umum. 